\section{俩 Heighten Science \\ P U B L I C I T I I N S Corporation ISSN 2575-0135}

\title{
Phytochemical content of leaf and stem of Marsilea quadrifolia (L.)
}

\author{
Karikalan Gopalakrishnan and Rajangam Udayakumar* \\ Post Graduate and Research Department of Biochemistry, Government Arts College \\ (Autonomous), Kumbakonam-612001, Tamilnadu, India
}

\section{*Address for Correspondence: Rajangam Udayakumar, Post Graduate and Research Department of Biochemistry, Government Arts College (Autonomous), Kumbakonam-612001, Tamilnadu, India, E-mail: \\ udayabiochem@yahoo.co.in}

Submitted: 31 December 2017

Approved: 22 May 2017

Published: 23 May 2017

Copyright: @ 2017 Gopalakrishnan K, et al. This is an open access article distributed under the Creative Commons Attribution License, which permits unrestricted use, distribution, and reproduction in any medium, provided the original work is properly cited.

Keywords: Marsilea quadrifolia; Leaf; Stem; Phytocompounds; Methanolic; Aqueous

\section{ABSTRACT}

The present study was aimed to screen and quantify the phytochemicals by qualitative and quantitative analysis in methanol and aqueous leaf and stem extracts of Marsilea quadrifolia (L.). In qualitative analysis, the phytochemical compounds such as tannins, saponins, flavonoids, steroids, terpenoids, triterpenoids, alkaloids, carbohydrates, proteins, anthroquinones, phenolic compounds and phytosterol were screened. Among these phytocompounds tannins, saponins, flavonoids, steroids, alkaloids, carbohydrates, proteins and phenolic compounds were observed in methanol and aqueous leaf and stem extracts of M. quadrifolia. Anthroquinones were absent in both leaf and stem extracts of $M$. quadrifolia. The content of phenolic compounds $8.34 \pm 0.92$ $\mathrm{mg} / \mathrm{g}$ and $7.31 \pm 0.46 \mathrm{mg} / \mathrm{g}$, flavonoids $7.46 \pm 0.64 \mathrm{mg} / \mathrm{g}$ and $6.45 \pm 0.68 \mathrm{mg} / \mathrm{g}$, alkaloids $6.12 \pm 0.51 \mathrm{mg} / \mathrm{g}$ and $5.89 \pm 0.61 \mathrm{mg} / \mathrm{g}$, tannins $6.58 \pm 0.72 \mathrm{mg} / \mathrm{g}$ and $6.07 \pm 0.56 \mathrm{mg} / \mathrm{g}$ and saponins $5.32 \pm 0.48 \mathrm{mg} / \mathrm{g}$ and $6.30 \pm 0.58$ $\mathrm{mg} / \mathrm{g}$ were determined in leaf and stem of $M$. quadrifolia, respectively. So, the present study confirmed that the presence of phytocompounds in leaf and stem of M. quadrifolia.

\section{INTRODUCTION}

India has one of the oldest, richest and most diverse cultural traditions associated with the use of medicinal plants. Medicinal plants are the richest bioresource of drugs of traditional systems of medicine, modern medicines, nutraceuticals, food supplements, folk medicines, pharmaceutical intermediates and chemical entities for synthetic drugs [1]. Traditional knowledge is the base of modified systems of medicine and exists in the forms of Ayurveda, Unani, Siddha and Swa-riga (Tibetan) systems of medicine [2]. Medicinal plants contain some organic compounds which provide definite physiological action on the human body and these bioactive substances are including tannins, alkaloids, carbohydrates, terpenoids, steroids and flavonoids [3]. These compounds are synthesized by primary or secondary metabolism of living organisms. Secondary metabolites are chemically and taxonomically extremely diverse compounds with obscure function. They are widely used in human therapy, veterinary, agriculture, scientific research and countless other areas [4]. A large number of phytochemicals have been shown to possess inhibitory effects on all types of microorganisms in vitro [5].

Most of the modern drugs have been developed from plants based on the traditional knowledge. In traditional societies nutrition and health care are strongly interconnected and many plants have been consumed both as food and for medicinal purposes [6]. The significance of medicinal plant is directly linked to the wide range of chemical compounds synthesised by various biochemical pathways. These compounds are classified as secondary plant products, because they are not much related to plant survival, but they are known to possess many important functions. The importance of natural molecules in medicine lies not only in their pharmaceutical or chemotherapeutic effects but also in their role as template molecules for the production of synthetic drugs [7]. 
Today natural products derived from plants are being tested for presence of new drugs with new modes of pharmacological action [8]. Plants are used as medicine in many countries and also act as a source for many potent drugs [9]. A large number of medicinal plants and their purified constituents have shown therapeutic activities [10]. Natural remedies from medicinal plants proved as safe and effective. Many plant species have been used in folklore medicine to treat various ailments [11]. Phytocompounds from medicinal plants are important in pharmaceutical industry for drug development and preparation of therapeutic agents [12]. The development of pharmaceuticals begins with identification of active principles, detailed biological assays and dosage formulations followed by clinical studies to establish safety, efficacy and pharmacokinetic profile of new drug [13].

Plant phenolics have potential health benefits mainly due to their antioxidant properties such as reactive oxygen species (ROS) scavenging and inhibition, electrophile scavenging and metal chelation [14]. Epidemiological studies support a relationship between consumption of phenolic rich food products and low incidence of coronary heart disease [15], atherosclerosis [16], certain forms of cancer [17] and stroke [18]. The chemistry and nutritional properties of phenolic compounds have been extensively reviewed [19].

Flavonoids are compounds that exist in plants as secondary metabolites. Over 4000 flavonoids have been identified, purified and their structures determined. Flavonoids and flavones are widely distributed secondary metabolites with antioxidant and antiradical properties [20]. Alkaloids have diverse structures and many showed a range of pharmacological activities including antimicrobial activity [21]. Tannins are abundant in many plant parts including the fruits, cortex, leaves, roots and other parts [22]. Tannins are as polyphenols, have antioxidant [23] and immunological [24] properties. Saponins are a diverse group of compounds widely distributed in the plant kingdom. The presence of saponins has been reported in more than 100 families of plants, and in a few marine sources such as star fish and sea cucumber [25]. The research has established saponins as the active components in many herbal medicines [26] and highlighted their contributions to the health benefits of foods such as soybeans [27] and garlic [28]. The natural saponins have been found to possess significant anticancer properties [29]. The identification and development of saponins have greatly contributed to medical treatment and many of these compounds are now being used in clinical practice.

Marsilea quadrifolia is an important medicinal plant. M. quadrifolia is beneficial for nutrient mitigation from the fresh water of lake and significant progress has been made for wetland restoration [30]. It is commonly known as four leaf clover, water clover, pepperwort and water shamrock and it is also commonly called as Sushni in parts of India and Aarai keerai or Aala keerai in Tamilnadu, India. The plant M.quadrifolia has diverse medicinal properties and also it is in use for more than 3000 years as part of food. It is used in the Ayurvedic System of Medicine for curing several ailments. M. quadrifolia is used to treat cough, bronchitis, diabetes, psychiatric diseases, eye diseases, diarrhoea and skin diseases. It is usually grows in mud, on damp soils, or often in shallow ponds and pools in India. M. quadrifolia was introduced into the Northern United States over 100 years ago from Europe. M. quadrifolia is recognized as a serious weed in rice fields of numerous countries particularly in Asia. M. quadrifolia is a green vegetable in South India and it is distributed Central and Southern Europe, Western Siberia, Afghanistan, South India, China, Japan and North America. A very few studies are available on phytochemical composition of $M$. quadrifolia, but there is no report on quantification of phytocompounds in leaf and stem of M. quadrifolia. So, the present study was aimed to identify the presence or absence and to determine the amount of phytocompounds such as phenolic compounds, flavonoids, alkaloids, tannins and saponins in leaf and stem of M. quadrifolia. 


\section{MATERIALS AND METHODS}

\section{Chemicals}

Gallic acid, Quercetin dehydrates and Tannic acid was purchased from Sigma Chemicals Co. St. Louis, Mo, USA. Solvents (methanol) were of HPLC grade purchased from Fischer Scientific Chemicals Co. Fair Lawn, NJ, USA. All other chemicals and reagents were of analytical grade and purchased from reputed chemical companies.

\section{Collection, identification and preparation of plant material}

The fresh plants of $M$. quadrifolia were collected from natural habitats of Pathur Village, Tiruvarur District, Tamilnadu, India during the months of November and December 2014. The collected plant was identified by Rev. Dr. S. John Britto, Director, Rabinet Herbarium and Centre for Molecular Systematics, St. Joseph's College, Tiruchirappalli, Tamilnadu, India and deposited in the herbarium (Voucher specimen number: KG001). The plants were washed thoroughly in running tap water to remove soil particles and adhered debris from it and finally washed with distilled water. The stem and leaves of $M$. quadrifolia were separated and shade dried for 15 days at room temperature. Then the plant materials were ground well into fine powder. The powdered materials were stored in air tight containers until the time of use.

\section{Preparation of plant extract}

The extracts of leaf and stem of $M$. quadrifolia were prepared. For this, $20 \mathrm{~g}$ of leaf and stem powder of $M$. quadrifolia was soaked in $200 \mathrm{ml}$ of distilled water and methanol separately and kept in shaker for $48 \mathrm{~h}$. After $48 \mathrm{~h}$, it was filtered through Whatman no. 1 filter paper and then the volume of supernatant was concentrated at $40{ }^{\circ} \mathrm{C}$ using hot air oven. The concentrated aqueous and methanolic extracts of leaf and stem of M. quadrifolia were used for qualitative phytochemical analysis. The powdered plant materials were used in the estimation of alkaloids, tannins and saponins.

\section{Preliminary phytochemical screening}

Preliminary phytochemical screening was carried out in aqueous and methanolic leaf and stem extracts of M. quadrifolia for the analysis of tannins, saponins, flavonoids, steroids, terpenoids, triterpenoids, alkaloids, carbohydrates, proteins, anthroquinones, phenolic compounds and phytosterols by standard procedures [31].

\section{Test for tannins}

About $10 \mathrm{ml}$ of plant extract was taken in a test tube and added a few drops of $0.1 \%$ ferric chloride. Appearance of brownish green or blue-black colour indicates the presence of tannins.

\section{Test for saponins}

$10 \mathrm{ml}$ of plant extract was taken in a test tube and mixed with $5 \mathrm{ml}$ of distilled water and shaken vigorously for a stable persistent froth. The frothing was mixed with 3 drops of olive oil and shaken vigorously, then observed the formation of emulsion, which indicates the presence of saponins.

\section{Test for flavonoids}

a. $5 \mathrm{ml}$ of diluted ammonia solution was added to a portion of the plant extract followed by addition of concentrated $\mathrm{H}_{2} \mathrm{SO}_{4}$. A yellow colouration was observed, which indicates the presence of flavonoids. The yellow colour was disappeared on standing.

b. A few drops of $1 \%$ aluminium chloride solution were added to a portion of plant extract. A yellow colouration was observed and it indicates the presence of flavonoids. 
c. A portion of the plant extract was heated with $10 \mathrm{ml}$ of ethyl acetate over a steam bath for $3 \mathrm{~min}$. The mixture was filtered and $4 \mathrm{ml}$ of the filtrate was shaken with $1 \mathrm{ml}$ of diluted ammonia solution. A yellow colouration was observed which indicates the presence of flavonoids.

\section{Test for steroids}

$2 \mathrm{ml}$ of acetic anhydride was added to $0.5 \mathrm{~g}$ of extract with $2 \mathrm{ml}$ of $\mathrm{H}_{2} \mathrm{SO}_{4}$. The colour changed from violet to blue or green, which indicates the presence of steroids.

\section{Test for terpenoids (Salkowski test)}

$5 \mathrm{ml}$ of plant extract was mixed with $2 \mathrm{ml}$ of chloroform and $3 \mathrm{ml}$ of concentrated $\mathrm{H}_{2} \mathrm{SO}_{4}$ was carefully added to form a layer. A reddish brown colouration in the interface was formed which indicates the presence of terpenoids.

\section{Test for triterpenoids}

$10 \mathrm{mg}$ of the extract was dissolved in $1 \mathrm{ml}$ of chloroform and then added $1 \mathrm{ml}$ of acetic anhydride and $2 \mathrm{ml}$ of concentrated $\mathrm{H}_{2} \mathrm{SO}_{4}$. Formation of reddish violet colour indicates the presence of triterpenoids.

\section{Test for alkaloids}

a. $5 \mathrm{ml}$ of plant extract was added to $2 \mathrm{ml}$ of $\mathrm{HCl}$. To this acidic medium, $1 \mathrm{ml}$ of Dragendroff's reagent was added. An orange or red precipitate produced immediately indicates the presence of alkaloids.

b. Mayer's test. A few $\mathrm{ml}$ of the extract was taken and a drop of Mayer's reagent was added by the side of the test tube. A creamy or white precipitate formed indicates the presence of alkaloids.

\section{Test for carbohydrates (Benedict's test)}

To $0.5 \mathrm{ml}$ of the plant extract, $0.5 \mathrm{ml}$ of Benedict's reagent was added. The mixture was heated on boiling water bath for $2 \mathrm{~min}$. A characteristic red coloured precipitate indicates the presence of sugar.

\section{Test for proteins}

$1 \mathrm{ml}$ of plant extract was taken and added $1 \mathrm{ml}$ of $40 \%$ sodium hydroxide and then added a few drops of copper sulphate slowly in the sides of test tube. Appearance of violet or pink colour indicates the presence of proteins.

\section{Test for anthroquinones}

$5 \mathrm{ml}$ of the extract was hydrolyzed with concentrated $\mathrm{H}_{2} \mathrm{SO}_{4}$ and then $1 \mathrm{ml}$ of dilute ammonia was added. Formation of rose pink coloration indicates that the presence of anthroquinones.

\section{Test for polyphenols}

$10 \mathrm{ml}$ of ethanol was added to the extract and then $3 \mathrm{ml}$ of the resulting solution was transferred to test tube and incubated in a water bath for 15 minutes. Then 3 drops of freshly prepared ferric cyanide was added. Formation of a blue green colour indicates the presence of polyphenols.

\section{Test for phytosterol}

The extract was refluxed with solution of alcoholic potassium hydroxide till complete saponification takes place. The mixture was diluted and extracted with ether. The ether layer was evaporated and the residue was tested for the presence of phytosterol. The residue was dissolved in a few drops of diluted acetic acid and then 
added $3 \mathrm{ml}$ of acetic anhydride followed by a few drops of Conc. $\mathrm{H}_{2} \mathrm{SO}_{4}$. Appearance of bluish green colour indicates the presence of phytosterol.

\section{Quantitative phytochemical analysis}

The quantitative determination of phytocompounds such as total phenolic compounds, flavonoids, alkaloids, tannins and saponins in leaf and stem of M. quadrifolia were analysed by standard methods.

\section{Estimation of total phenolic compounds [32]}

The content of total phenolic compounds in methanolic extracts of leaf and stem of M. quadifolia was determined by Folin-Ciocalteu method (1927). For the preparation of calibration curve $1 \mathrm{ml}$ aliquots of $0.024,0.075,0.105$ and $0.3 \mathrm{mg} / \mathrm{ml}$ ethanolic gallic acid solutions were mixed with $5 \mathrm{ml}$ of Folin-Ciocalteu reagent and $4 \mathrm{ml}(75 \mathrm{~g} / \mathrm{l})$ of sodium carbonate. The absorption was read after $30 \mathrm{~min}$ at $765 \mathrm{~nm}$ in $20{ }^{\circ} \mathrm{C}$ and the calibration curve was drawn. $1 \mathrm{ml}$ of methanolic extract $(10 \mathrm{~g} / \mathrm{l})$ was mixed with the same reagents as described above, and after $1 \mathrm{~h}$ the absorption was measured for the determination of plant phenolics. All determinations were performed in triplicate. The total content of phenolic compounds in methanolic extracts in gallic acid equivalents (GAE) was calculated by the following formula:

Total phenolic content $(\mathrm{mg} / \mathrm{g}$ of plant extract in $\mathrm{GAE})=$

Concentration of gallic acid established from the calibration curve $(\mathrm{mg} / \mathrm{ml}) \times \frac{\text { Volume of extract }(\mathrm{ml})}{\text { Weight of pure plant methanolic extracts }(\mathrm{g})}$

\section{Estimation of flavonoids content [33]}

The content of flavonoids was determined by the Pharmacopoeia method (1989) and using quercetin as a reference compound. $1 \mathrm{ml}$ of plant extract in methanol $(10 \mathrm{~g} / \mathrm{l})$ was mixed with $1 \mathrm{ml}$ of aluminiumtrichloride in ethanol $(20 \mathrm{~g} / \mathrm{l})$ and diluted to 25 $\mathrm{ml}$ with ethanol. The absorption at $415 \mathrm{~nm}$ was read after 40 minutes at $20^{\circ} \mathrm{C}$. Blank sample was prepared from $1 \mathrm{ml}$ of plant extract and 1 drop of acetic acid, and diluted to $25 \mathrm{ml}$. The absorption of quercetin solutions was measured under the same conditions. Standard quercetin solution was prepared from $0.05 \mathrm{~g}$ quercetin solution $(0.05 \mathrm{~g} / \mathrm{l})$. All determinations were carried out in triplicate. The amount of flavonoids in plant extracts in quercetin equivalents (QE) was calculated by the following formula:

Flavonoid content $(\mathrm{mg} / \mathrm{g}$ of plant extract in $\mathrm{QE})=$

$$
\frac{\text { Absorption of plant extract solution }}{\text { Absorption of standard quercetin solution }} \times \frac{\text { Weight of quercetin in the solution }(\mathrm{g})}{\text { Weight of plant extract }(\mathrm{g})} \times 10
$$

\section{Estimation of alkaloids [34]}

$5 \mathrm{~g}$ of the sample was weighed and transferred into $250 \mathrm{ml}$ beaker and $10 \%$ acetic acid in ethanol was added and covered and allowed to stand for 4 hours. This was filtered and the extract was concentrated on a water bath to one quarter of the original volume. Concentrated ammonium hydroxide was added drop wise to the extract until precipitation was complete. The whole solution allowed to settle and the precipitate was collected and washed with dilute ammonium hydroxide and then filtered. The residue is the alkaloid, which was dried and weighed. All determinations were carried out in triplicate.

\section{Estimation of tannins content [35]}

0.2-1.0 $\mathrm{ml}$ of standard tannic acid solution was pipetted out into a series of test tubes. In another test tube $0.5 \mathrm{ml}$ of extract solution was taken. The volumes of all the tubes were made up to $3.0 \mathrm{ml}$ with distilled water. $3.0 \mathrm{ml}$ of distilled water was 
taken as blank. To all the tubes added $5.0 \mathrm{ml}$ of $20 \% \mathrm{Na}_{2} \mathrm{CO}_{3}$ followed by the addition of $2.5 \mathrm{ml}$ of Folin-Dennis reagent and incubated at room temperature for 30 minutes. The absorbance was read against reagent blank at 700nm. From the standard graph the amount of tannins present in the sample was calculated. All determinations were carried out in triplicate.

\section{Estimation of saponins [36]}

$20 \mathrm{~g}$ of sample was mixed with $200 \mathrm{ml}$ of $20 \%$ aqueous ethanol. The suspension was heated using a water bath for 4 hours with constant stirring at about $55^{\circ} \mathrm{C}$. The mixture was filtered and the residue re-extracted with another $200 \mathrm{ml}$ of $20 \%$ ethanol. The combined extracts were reduced to $40 \mathrm{ml}$ over water bath at about $90^{\circ} \mathrm{C}$. The concentrated extract was transferred into $250 \mathrm{ml}$ separating funnel and $20 \mathrm{ml}$ of diethyl ether was added and shaken vigorously. The aqueous layer was recovered while the ether layer discarded. The purification process was repeated and then 60 $\mathrm{ml}$ of $\mathrm{n}$-butanol was added. The combined n-butanol extracts were washed twice with $10 \mathrm{ml}$ of $5 \%$ aqueous $\mathrm{NaCl}$. The remaining solution was heated in a water bath. After evaporation, the sample was dried in an oven until to get a constant weight and then saponins contents were calculated in percentage. All determinations were carried out in triplicate.

\section{STATISTICAL ANALYSIS}

The results of the present study were subjected to statistical analysis and the results were expressed as mean \pm standard deviation of three determinations.

\section{RESULTS}

Phytocompounds such as tannins, saponins, flavonoids, steroids, terpenoids, triterpenoids, alkaloids, carbohydrates, proteins, anthroquinones, phenolic compounds and phytosterol were screened in methanol and aqueous extracts of leaf and stem of M. quadrifolia and the results were showed in table 1. Among these compounds, the important secondary metabolites such as phenolic compounds, flavonoids, alkaloids, tannins and saponins were present in both methanol and aqueous extracts of leaf and stem of M. quadrifolia.

Quantitative phytochemical tests for tannins, saponins, flavonoids, steroids, alkaloids, carbohydrates, proteins and phenolic compounds were revealed positive results in aqueous and methanolic leaf extracts of $M$. quadrifolia. The test for phytosterols was revealed positive result in methanolic leaf and stems extracts and negative results in aqueous leaf and stem extracts. The qualitative phytochemical tests for terpenoids, triterpenoids and anthroquinones were showed negative results in aqueous and methanolic leaf extracts of M. quadrifolia.

Table 1: Preliminary phytochemical analysis of methanol and aqueous extracts of leaf and stem of M. quadrifolia.

\begin{tabular}{|c|c|c|c|c|}
\hline \multirow{2}{*}{$\begin{array}{c}\text { Name of } \\
\text { phytocompounds }\end{array}$} & Methanolic extract & Aqueous extract & Methanolic extract & Aqueous extract \\
\hline Tannins & + & + & + & + \\
\hline Saponins & + & + & + & + \\
\hline Flavonoids & + & + & + & + \\
\hline Steroids & + & + & + & + \\
\hline Terpenoids & - & - & + & + \\
\hline Triterpenoids & - & - & + & + \\
\hline Alkaloids & + & + & + & + \\
\hline Carbohydrates & + & + & + & + \\
\hline Proteins & + & + & + & + \\
\hline Anthroquinones & - & - & + & + \\
\hline Phenolic compounds & + & + & + & + \\
\hline Phytosterols & + & - & + \\
\hline
\end{tabular}


Phytochemical tests for tannins, saponins, flavonoids, steroids, terpenoids, alkaloids, carbohydrates, proteins and phenolic compounds and phytosterols were showed positive results in aqueous and methanolic stem extracts. The tests for triterpenoids was showed positive results in methanolic stem extract and the test for anthroquinones was showed negative result in methanolic stem extract and the tests for triterpenoids, anthroquinone and phytosterols were showed negative results in aqueous stem extract of $M$. quadrifolia.

The amount of phytocompounds like phenolic compounds, flavonoids, alkaloids, tannins and saponins were quantitatively determined in leaf and stem of M. quadrifolia and the results were given in table 2 . Among the five phytocompounds, phenolic compounds content was higher $8.34 \pm 0.92 \mathrm{mg} / \mathrm{g}$ in leaf of $M$. quadrifolia than stem $7.31 \pm 0.46 \mathrm{mg} / \mathrm{g}$. The flavonoids content was $7.46 \pm 0.64 \mathrm{mg} / \mathrm{g}$ in leaf of $M$. quadrifolia followed by stem $6.45 \pm 0.68 \mathrm{mg} / \mathrm{g}$. The amount of alkaloids $6.12 \pm 0.51 \mathrm{mg} / \mathrm{g}$ and $5.89 \pm 0.61 \mathrm{mg} / \mathrm{g}$ were determined in leaf and stem of $M$. quadrifolia, respectively. The amount of tannins $6.58 \pm 0.72 \mathrm{mg} / \mathrm{g}$ in leaf and $6.07 \pm 0.56 \mathrm{mg} / \mathrm{g}$ in stem was determined. The amount of saponins was found as $5.32 \pm 0.48 \mathrm{mg} / \mathrm{g}$ in leaf and $6.30 \pm 0.58 \mathrm{mg} / \mathrm{g}$ in stem of M. quadrifolia.

\section{DISCUSSION}

Medicinal plants are of great importance to the health of individual and communities. The active chemical substances of medicinal plants are produced a definite physiological action on human body. The most important of these chemically active constituents of plants are phenolic compounds, flavonoids, alkaloids, tannins and saponins. Many of the indigenous medicinal plants are used for medicinal purposes [37]. The use of plants and plant extracts provides the foundation to modern therapeutic science and thus enabled the man to establish the empirical system of medicine.

Phytochemical screening of the medicinal plants is very helpful for the development of new drugs [38]. Phytochemicals of plant extracts are known to exhibit medicinal as well as physiological activities [39]. For centuries, extracts from plants have been used as folk remedies against various health problems [40] and with many natural products are leading to the development of clinically beneficial drugs [41]. In the present study, phytochemical analysis of the extracts of leaf and stem of $M$. quadrifolia revealed that the presence of tannins, saponins, flavonoids, steroids, terpenoids, alkaloids, carbohydrates, proteins and phenolic compounds. The content of phytocompounds like total phenolic compounds, flavonoids, alkaloids, tannins and saponins in leaf and stem of M. quadrifolia extracts were also determined. The results showed that phenolic and flavonoid compounds were found in different quantities in different tissues. Similar results were reported in carrots [42] and Miliauskas et al. (2004) reported that the content of phenolic compounds and flavonoids of some medicinal and aromatic plant extracts. Rembold (1989) reported that the Azadirachta indica contains substances like nimbin, terpenoids, azadirone and azadiractin and these substances are used as antimicrobial drug for treating various infectious diseases. Various phytoconstituents like diterpenoids and flavonoids have been isolated from Caesalpinia pulcherrima

Table 2: The content of phenolic compounds, flavonoids, alkaloids, tannins and saponins in leaf and stem of M. quadrifolia.

\begin{tabular}{|c|c|c|}
\hline Name of phytocompounds & Leaf & Stem \\
\hline Phenolic compounds (mg/g plant extract in gallic acid equivalents) & $8.34 \pm 0.92$ & $7.31 \pm 0.46$ \\
\hline Flavonoids (mg/g plant extract in quercetin equivalents) & $7.46 \pm 0.64$ & $6.45 \pm 0.68$ \\
\hline Alkaloids $(\mathrm{mg} / \mathrm{g})$ & $6.12 \pm 0.51$ & $5.89 \pm 0.61$ \\
\hline Tannins $(\mathrm{mg} / \mathrm{g})$ & $6.58 \pm 0.72$ & $6.07 \pm 0.56$ \\
\hline Saponins $(\mathrm{mg} / \mathrm{g})$ & $5.32 \pm 0.48$ & $6.30 \pm 0.58$ \\
\hline Values are expressed as mean \pm SD of three determinations. & & \\
\hline
\end{tabular}


[43]. Despite the remarkable progress in synthetic organic chemistry of the twentieth century, over $25 \%$ of the medicines used in industrialized countries are derived directly or indirectly from plants [44]. Phytocompounds are naturally synthesized in all parts of the plant like bark, leaves, stem, root, flower, fruits, seeds, etc and the quantity and quality of phytochemicals present in plant parts may differ from one another [45].

Traditional knowledge of medicinal plants has always guided the search for new drugs. Authentication of medicinal plants in genetic and chemical level is a critical step in the use of these botanical materials for both research purposes and commercial preparations [11]. In spite of the advantage of modern high throughput drug discovery and screening techniques, traditional medicinal knowledge have also given clues to the discovery of valuable drugs [46]. There is growing awareness in correlating the phytochemical compounds with their biological activities [47].

The phenolic compounds are one of the largest and most ubiquitous groups of plant metabolites [48]. Phenolic compounds possess therapeutic properties such as antiapoptosis, antiaging, anticarcinogen, antiinflammation, antiatherosclerosis, cardiovascular protection and improvement of endothelial function, as well as inhibition of angiogenesis and cell proliferation activities [49]. It is well known that plant polyphenols are widely distributed in the plant kingdom and they are sometimes present in surprisingly high concentrations [50]. Polyphenolic compounds have an important role in stabilizing lipid oxidation and are associated with antioxidant activity [51]. The phenolic compounds may contribute directly to antioxidative action [52]. It is suggested that polyphenolic compounds have inhibitory effects on mutagenesis and carcinogenesis in humans when up to $1.0 \mathrm{~g}$ is daily ingested from the diet rich in fruits and vegetables [53].

Flavonoids are one of the most diverse and widespread groups of natural compounds possess a broad spectrum of radical scavenging properties [54]. Plants containing flavonoids have been reported to possess antioxidant properties [55]. Flavonoids have been reported to have numerous medicinal effects, including antioxidant, vasoprotective, anti-inflammatory, antiviral, antibacterial, and antitumor [56]. Flavonoids and flavones are widely distributed secondary metabolites with antioxidant and antiradical properties [57]. The alkaloid extracts obtained from medicinal plant species have multiplicity of host-mediated biological activities, including antimalarial, antimicrobial, antihyperglycemic, anti-inflammatory and pharmacological effects [58].

Tannins are naturally occurring plant polyphenols and their main characteristic is that they bind and precipitate proteins. They can have a large influence on the nutritive value of many foods eaten by humans and feedstuff eaten by animals. Tannins are common in fruits, tea, chocolate, legume forages, legume trees and grasses. Studies have shown that tannins possess antidiarrhoeal and antimicrobial activities [59].

Saponins have been reported to possess a wide range of biological activities [60]. Saponins can impact the immune system through their adjuvant activity, their ability to improve the effectiveness of orally administered vaccines by facilitating the absorption of large molecules and their immunostimulatory effects. Saponins are widely distributed in many plants and are relatively widespread in our foodstuffs and herbal preparations. They also exhibit a variety of biological activities, and have been investigated towards the development of new natural medicines and prove the efficacy of traditional herbal medicines [61]. Other interesting biological applications for various specific saponins include their uses as anti-inflammatory [62], hypocholesterolemic [27] and immune-stimulating [63] activities, whose properties are widely recognized and commercially utilized. Saponins have been possessed a number of pharmacological actions including, immunomodulatory potential via cytokine interplay [64], cytostatic and cytotoxic effect on malignant tumor cell [65], adjuvant properties for vaccines as immune stimulatory complexes [66] and synergistic enhancement of the toxicity of immunotoxins [67]. 
Plants are a valuable source of new natural products. Despite the availability of different approaches for the discovery of therapeuticals, natural products still remain one of the best reservoirs of new structural types. The phytochemical tests of M. quadrifolia indicated that the presence of alkaloids, glycosides, flavonoids, phytosterols, fixed oils and fats, phenols, tannins and saponins in the crude methanolic and aqueous leaf and stem extracts. Several such compounds were known to possess potent antioxidant activity [68]. Similarly the qualitative and quantitative analysis of phytochemicals in Marsilea minuta was reported [69] and the Phytochemicals of leaves and petiole extracts of Marsilea minuta (L.) were also reported [70]. The isolation of individual phytochemical constituents from leaf and stem of $M$. quadrifolia and subjecting it to biological activity will definitely give fruitful results. The phytochemical analysis of the medicinal plants is important and has commercial interest in both research institutes and pharmaceutical companies to develop new drugs for the treatment of various diseases. Thus the isolation and purification of important phytochemicals were identified in leaf and stem of $M$. quadrifolia may be useful in the treatment of various diseases.

\section{ACKNOWLEDGEMENT}

This research work was financially supported by the University Grants Commission [UGCMRP-F. No. 42-638/2013 (SR)], New Delhi, India.

\section{REFERENCES}

1. Ncube NS, Afolayan AJ, Okoh Al. Assessment techniques of antimicrobial properties of natural compounds of plant origin: current methods and future trends. Afr J Biotechnol. 2008; 7: 1797-1806. Ref.: https://goo.gl/haE1w1

2. Mehta Kavit, Patel BN, Jain BK. Phytochemical analysis of leaf extract of Phyllanthus fraternus. Research Journal of Recent Sciences. 2013; 2: 12-15.

3. Edeoga HO, Okwu DE, Mbaebie BO. Phytochemical constituents of some Nigerian medicinal plants. Afr J Biotechnol. 2005; 4: 685-688. Ref.: https://goo.gl/rCK3LA

4. Vasu K, Goud JV, Suryam Z, Suryam A, Charya S. Biomolecular and phytochemical analyses of three aquatic angiosperms. Afr JMicrobiol Res. 2009; 3: 418-421. Ref.: https://goo.gl/kpw0XY

5. Cowan MM. Plant products as antimicrobial agents. Clin Microbiol Rev. 1999; 564-582. Ref.: https://goo.gl/kKE4rO

6. Etkin NL. Medicinal cuisines: diet and ethnopharmacology. Int J Pharm.1996; 34: 313-326. Ref.: https://goo.gl/KckvgV

7. AmeyawY, Duker-Eshun G. The alkaloid contents of the ethno-plant organs of three antimalarial medicinal plant species in the eastern region of Ghana. Int J ChemSci. 2009; 7: 48-58 Ref.: https://goo.gl/EYMlbL

8. Gopalakrishnan K, Udayakumar R. GC-MS Analysis of Phytocompounds of Leafand Stem of Marsilea quadrifolia (L.). International Journal of Biochemistry Research \& Review. 2014; 4: 517-526. Ref.: https://goo.gl/7PMo2p

9. Mahesh B, Satish S. Antimicrobial activity of some important medicinal plant against plant and human Pathogens. World J Agric Sci. 2008; 4: 839-843. Ref.: https://goo.gl/wbyfrm

10. Janakiraman N, Johnson M, Sahaya Sathish S. GC-MS analysis of bioactive constituents of Peristrophe bicalyculata (Retz.) Nees. (Acanthaceae). Asian Pac J Trop Biomed. 2012; 2: 46-49. Ref.: https://goo.gl/4WRRr8

11. Balamurugan K, Nishanthini A, Mohan VR. GC-MS analysis of Polycarpaea corymbosa (L.) Lam whole plant. Asian Pac J Trop. 2012; 2: 1289-1292. Ref.: https://goo.gl/5w5QZp

12. Nisha K, Darshana M, Madhu G, Bhupendra MK. GC-MS analysis and anti-microbial activity of Psidium guajava (leaves) grown in Malva region of India. Int J Drug Dev \& Res. 201 1; 3: 237-245. Ref.: https://goo.gl/XvSdbP

13. Mehdi SJ, Ahmad A, Irshad M, Nikhat Manzoor, Moshahid Alam Rizvi M. Cytotoxic effect of Carvacrol on human cervical cancer cells. Biology and Medicine. 2011; 3: 307-312. Ref.: https://goo.gl/MhzlwW 
14. Huang MT, Ho CT, Lee CY. Phenolic compounds in food and their effects on health. II: Antioxidants and cancer prevention. Amer Chem Soc Sym Seri. 507. Washington: American Chemical Society.1992; 2-7.

15. Hertog MG, Feskens EJ, Holloman PC, Katan MB, Kromhout D. Dietary antioxidant flavonoids and risk of caronary heart disease. Lancet. 1993; 342: 1007-1011. Ref.: https://goo.gl/CVf5wZ

16. Diaz MN, Frei B, Vita JA, Keaney JF Jr. Antioxidants and atherosclerotic heart disease. New Engl. J. Med. 1997; 337: 408-416. Ref.: https://goo.gl/NiGqNq

17. Ito N, Hirose M. Antioxidants-carcinogenic and chemo-preventive properties. Adv Cancer Res. 1989 53: 247-302. Ref.: https://goo.gl/rWuiZX

18. Ness AR, Powles JW. Fruit and vegetables and cardiovascular disease: a review. Int J Epidemiol. 1997; 26: 1-13. Ref.: https://goo.gl/wMFkws

19. Yang B, Kotani A, Arai K, Kusu F. Estimation of the antioxidant activities of flavonoids from their oxidation potentials. Anal Sci. 2001; 17: 599-604. Ref.: https://goo.gl/ZEznOp

20. Nakayoma J, Yamada M, Osawa T, Kawakishi S. Suppression of active oxygen-induced cytotoxicity by flavonoids. Biochem Pharmacol. 1995; 45: 265-267. Ref.: https://goo.gl/7WdnSe

21. Ahmed A, Khan KA, Ahmad VU, Qazi S. Antibacterial Activity of Juliflorine Isolated from Prosopis juliflora. Planta Med. 1986; 4: 285-288. Ref.: https://goo.gl/xM3mWj

22. Chung KT, Wong TY, Wei Cl, Huang YW, Lin Y. Tannins and human health: a review. Crit Rev Food Sci. 1998; 38: 421- 464. Ref.: https://goo.gl/4El1jp

23. Bravo L. Polyphenols: chemistry, dietary sources, metabolism and nutritional significance. Nutrition Reviews. 1998; 56: 317-333. Ref.: https://goo.gl/olzH05

24. Scalbert A. Antimicrobial properties of tannins. Phytochem. 1991; 30: 3875-3883 Ref.: https://goo.gl/QDzmvx

25. Hostettmann K, Marston A. Saponins. Vol 1. 1st ed. Cambridge: Cambridge University Press. 1995.

26. Liu J. Henkel T. Traditional Chinese medicine (TCM): are polyphenols and saponins the key ingredients triggering biologicial activities? Curr Med Chem. 2002; 9: 1483- 1485. Ref.: https://goo.gl//u2nxC

27. Oakenfull D. Saponins in the treatment of hypercholesterolemia, In: Spiller GA (ed.) Handbook of Lipids in Human Nutrition. CRC Press. 1996; 107-112. Ref.: https://goo.gl/ODzkTN

28. Shams-Ghahfarokhi M, Shokoohamiri MR, Amirrajab N, Moghadasi B, Ghajari A, et al. In vitro antifungal activities of Allium cepa, Allium sativum and ketoconazole against some pathogenic yeasts and dermatophytes. Fitoterapia. 2006; 77: 321-323. Ref.: https://goo.gl/Mv0wtw

29. Man S, Gao W, Zhang Y, Huang L, Liu C. Chemical study and medical application of saponins as anticancer agents. Fitoterapia. 2010; 81: 703-714. Ref.: https://goo.gl/1QBRse

30. Soni $\mathrm{P}$, Singh L. Marsilea quadrifolia linn.-A valuable culinary and remedial fern in Jaduguda, Jharkhand, India. Life Science. 2012; 2: 99-106. Ref.: https://goo.gl/YmocMA

31. Sofowara A. Medicinal plants and Traditional medicine in Africa. Spectrum Books Ltd, Ibadan, Nigeria. 1993; 191-289

32. Hagerman A, Muller I, Makkar H. Quantification of tannins in tree foliage. A laboratory manual, Vienna: FAO/IAEA. 2000; 4-7.

33. Kumaran A, Karunakaran R. Antioxidant and free radical scavenging activity of an aqueous extracts of Coleus aromaticus. Food chemistry, 2006; 97: 109-114. Ref.: https://goo.gl/iWY8PO

34. Harborne JB. Phytochemical methods, London. Chapman and Hall. Ltd. 1973; 49-188.

35. Schendrel SH. Methods in food analysis Academic Press 1970; 749-756.

36. Obadoni BO, Ochuko PO. Phytochemical studies and comparative efficacy of the crude extract of some homeostatic plants in Edo and Delta states of Nigeria. Global J Pure Appl Sci. 2001; 8: 203-208. Ref.: https://goo.gl/qSWkkL

37. Aiyelaagbe 00, Paual Osamudiamen M. Phytochemical Screening For Active Compounds in Mangifera indica Leaves from Ibadan. Oya State. Plant Sci Res. 2009; 2: 11-13.

38. Wadood A, Ghufran M, Jamal SB, Naeem M, Khan A, et al. Phytochemical Analysis of Medicinal Plants Occurring in Local Area of Mardan anal biochem. 2013; 2: 2-4. Ref.: https://goo.gl/rxYb5W 
39. Sofowra A. Medicinal plants and Traditional medicine in Africa. Spectrum Books Ltd, Ibadan, Nigeria.1993; 191-289.

40. Kaileh M, Berghe WV, Boone E, Essawi T, Haegeman G. Screening of indigenous Palestinian medicinal plants for potential anti-inflammatory and cytotoxic activity. J Ethnopharmacol. 2007; 113: 510-516. Ref.: https://goo.gl/wjCGhW

41. Shu YZ. Recent natural products based drug development: a pharmaceutical industry perspective. J Nat Prod. 1998: 61: 1053-1071. Ref.: https://goo.gl/hnWk00

42. Zhang D, Hamauzu Y. Phenolic compounds and their antioxidant properties in different tissues of carrots (Daucuscarota L.). Food Agric Env. 2004; 2: 95-100. Ref.: https://goo.gl/izLVHL

43. Rao Y, Fang S, Tzeng Y. Antiinflammatory activities of flavonoids isolated from Caesalpinia pulcherrima. J Ethnopharmacol. 2005; 100: 249-253. Ref.: https://goo.gl/4SLBIs

44. Newman DJ, Cragg GM, Snader KM. The influence of natural products upon drug discovery. Nat Prod Rep. 2000; 17: 175-285. Ref.: https://goo.gl/4JSqZZ

45. Tiwari $P$, kumar $B$, Kaur M, G Kaur, H Kaur. Phytochemical screening and extraction: A review. International Pharmaceutical Sciencia. 2011; 1: 98-106.

46. Zibbu G, Batra A. GC-MS analysis of the desert plants of Apocynaceae family: Nerium oleander $L$. and Thevetiaperuviana Schum. International Journal of Pharmaceutical Research and Development. 2011; 3: 49-62.

47. Fernie AR, Trethewey RN, Krotzky AJ, Willmitzer L. Metabolite profiling: from diagnostics to system biology. Nat RevMol Cell Biol. 2004; 5: 763-769. Ref.: https://goo.gl/ALwlyE

48. Singh R, Singh SK, Kumar S, Arora S. Evaluation of antioxidant potential of ethyl acetate extract/ fractions of Acacia auriculiformis. A Cunn Food Chem Toxicol. 2007; 45: 1216-1223. Ref.: https://goo.gl/F76Fki

49. Han X, Shen T, Lou H. Dietry polyphenols and their biological significance. Int J Mol Sci. 2007; 8: 950 988. Ref.: https://goo.gl/nVjJFs

50. Harborne JB. Introduction to ecological biochemistry. 4th edition. Academic Press. London. 1993. Ref.: https://goo.gl/xfFPp7

51. Yen GC, Duh PD, Tsai CL. Relationship between antioxidant activity and maturity of peanut hulls. J Argic Food Chem. 1993; 41: 67-70. Ref.: https://goo.gl/uu95Ka

52. Duh PD, Tu YY, Yen GC. Antioxidant activity of water extracts of HarngJyur (Chyrsanthemum morifolium) of the families Combretaceae and Labiatae. J Ethnopharmacol. 1999; 37: 269-277. Ref.: https://goo.gl/Zf9C00

53. Tanaka M, Kuei CW, Nagashima Y. Application of antioxidative maillrad reaction products from histidine and glucose to saridine products. Nippon Suisan Gakkaishil. 1998; 54: 1409-1414. Ref.: https://goo.gl/vdM5hZ

54. Agarwel PK. Carbon-13 NMR of flavonoids. New York: Elsevier. 1989.

55. Bors W, Heller W, Michel C, Saran M. Flavonoids as antioxidants:determination of radical scavenging efficiencies. Methods Enzymol. 1990; 186: 345-355. Ref.: https://goo.gl/3ojISG

56. Cook NC, Samman S. Flavonoids-chemistry, metabolism, cardioprotective effects, and dietary sources. Nutr Biochem. 1996; 7: 66-76. Ref.: https://goo.gl/9g9lfO

57. Saboonchian F, Jamei R, Sarghein SH. Phenolic and flavonoid content of Elaeagnus angustifolia $\mathrm{L}$. (leaf and flower). Avicenna J Phytomed. 2014; 4: 231-238. Ref.: https://goo.gl/ITGHX1

58. Tackie AN, Schiff PL, Cryptospirolepine Jnr. A Unique Spiro-Noncyclic Alkaloid Isolated from Cryptolepis Sanguinolenta. J. Natural Products. 1993; 56: 653-65.

59. Tiana F, Lia B, Jia B, Yanga J, Zhangb G, et al. Antioxidant and antimicrobial activities of consecutive extracts from Gallachinensis: the polarity affects the bioactivities. Food Chem. 2009: 113: 173-179. Ref.: https://goo.gl/u4ceUs

60. Francis G, Kerem Z, Makkar HP, Becker K. The biological action of saponins in animal systems: a review. Br J Nutr. 2002; 88: 587-605. Ref.: https://goo.gl/GHkWle

61. Waller GR, Yamasaki K. Proceedings of an American Chemical Society Symposium on Saponins: Chicago, Illinois. 1995. 
62. Balandrin MF. Commercial Utilization of Plant-derived Saponins: An Overview of medicinal, Pharmaceutical and Industrial Applications, In: Waller GR and Yamasaki K. (eds) Saponins Used in Food and Agriculture: Plenum Press. 1996; 404: 1-14.

63. Klausner A. Adjuvants: a real shot in the arm for recombinant vaccines. Nature Biotechnology. 1988; 6: 773-777. Ref.: https://goo.gl/RzKsU5

64. Sun HX, Xie Y, Ye YP. Advances in saponin-based adjuvants. Vaccine. 2009; 27: 1787-1796. Ref.: https://goo.gl/Xlq0g5

65. Bachran C, Bachran S, Sutherland M, Bachran D, Fuchs H. Saponins in tumor therapy. Mini Rev Med Chem. 2008; 8: 575-584. Ref.: https://goo.gl/xJZM1X

66. Sjolander A, Cox JC, Barr IG. ISCOMs: an adjuvant with multiple functions. J Leukoc Biol. 1998; 64: 713-723. Ref.: https://goo.gl/zaFVtz

67. Bachran Ch, Heisler I, Bachran D, Dassler K, Matthias F, et al. Chimeric toxins inhibit growth of primary oral squamous cell carcinoma cells. Cancer Biol Ther. 2008; 7: 237-242. Ref.: https://goo.gl/uVYtHL

68. Lee J, Koo N, Min DB. Reactive oxygen species, aging and antioxidative neutraceuticals. Comp Rev Food Sci Food Safety. 2004; 3: 21-33. Ref.: https://goo.gl/3S848g

69. John de Britto A, Herin Sheeba Gracelin D, Benjamin Jeya Rathna Kumar P. Qualitative and quantitative analysis of phytochemicals in Marsilea minuta linn. Int J Pharm Bio Sci. 2013; 4: 800805. Ref.: https://goo.gl/300bi1

70. Revathi M, Catharin Sara S. Phytochemical studies onILeaves and Petiole extracts of Marsilea minuta L. International Journal of Science and Research. 2014; 3: 1872-1874. 